\title{
OPTIMIZATION OF THE CARROT LEAF DEHYDRATION AIMING AT THE PRESERVATION OF OMEGA-3 FATTY ACIDS
}

\author{
Vanessa Vivian de Almeida, Elton Guntendorfer Bonafé, Edvani Curti Muniz, Makoto Matsushita, Nilson Evelázio de \\ Souza e Jesuí Vergílio Visentainer* \\ Departamento de Química, Universidade Estadual de Maringá, Av. Colombo, 5790, 87020-900 Maringá - PR, Brasil
}

Recebido em 30/7/08; aceito em 9/12/08; publicado na web em 30/4/09

\begin{abstract}
The carrot leaf dehydration conditions in air circulation oven were optimized through response surface methodology (RSM) for minimizing the degradation of polyunsaturated fatty acids, particularly alpha-linolenic (LNA, 18:3n-3). The optimized leaf drying time and temperature were $43 \mathrm{~h}$ and $70{ }^{\circ} \mathrm{C}$, respectively. The fatty acids (FA) were investigated using gas chromatography equipped with a flame ionization detector and fused silica capillary column; FA were identified with standards and based on equivalent-chain-length. LNA and other FA were quantified against $\mathrm{C}_{21: 0}$ internal standard. After dehydration, the amount of LNA, quantified in mg/100 g dry matter of dehydrated carrot leaves, were $984 \mathrm{mg}$.
\end{abstract}

Keywords: alpha-linolenic acid; carrot leaves; optimized drying.

\section{INTRODUCTION}

The actual world nutritional is a paradox involving, at the same time, lack and excess of foods. It is known that most essential nutrients for human come from vegetal sources and that parts vegetable that might be used as food are wasted due to the lack of appropriate technologies. The development of new technologies targeting the use of such materials is now an important challenge for minimizing the squandering of food of potential-food ones as waste and, at same time, it is an alternative for reducing the pollution effects caused by food-wasting due their high organic content. Many researches have reported the elaboration of unconventional products as food..$^{1-5}$ They enhance the industrial efficiency reducing the growing accumulation of industrial waste that constitutes a source of contamination and hygienic and environmental problems.

Many vegetable leaves, including those of carrot (Daucus carota L.), are wasted. Carrot leaves are very rich in both nutrients such as vitamin $\mathrm{C}, \beta$-carotene, fibers and several minerals such as $\mathrm{Na}, \mathrm{P}, \mathrm{K}$, $\mathrm{Ca}, \mathrm{Mg}, \mathrm{Mn}, \mathrm{Zn}$, and $\mathrm{Fe} .{ }^{6}$ They have a pleasant taste and characteristics suitable for processing. They may be used as a raw basis for the preparation of several foods. The use of the by-products of the vegetable industry has presented technological viability, and they have been used for the formulation of cream soups made of dehydrated vegetable stalks. ${ }^{7}$

Plant leaf lipids usually contain large proportions of alphalinolenic acid (LNA, 18:3n-3), which is an important component of the chloroplast membrane lipids. ${ }^{8,9}$ Mammals who feed on these plants convert LNA by the same sequential desaturation and elongation enzyme systems. It results in the production of long chainpolyunsaturated fatty acids (n-3 LC-PUFA) which are reported to play an important role in human health. ${ }^{10}$

Carrot leaves, like others green leafy vegetables, are a good source of essential fatty acids, being LNA the predominant fatty acid. In the process for dehydration of carrot leaves aiming the conservation LNA the fresh leaves are converted in dry product rich in essential fatty acids that might be used as complementary food in the human nutrition.

The goal of the present study was to optimize the carrot leaf dehydration conditions in air circulation oven through the response

\footnotetext{
*e-mail: jvvisentainer@uem.br
}

surface methodology (RSM). It was investigated the suitable parameters to avoid the degradation of polyunsaturated fatty acids (PUFA), especially the LNA.

\section{EXPERIMENTAL}

\section{Sampling}

Leaves of carrot (organic, pesticide- and additive-free) were obtained from Paraná State producers ( $\left.23^{\circ} 25^{\prime} \mathrm{S}, 51^{\circ} 22^{\prime} \mathrm{W}\right)$. Eight kilograms of leaves were collected from the same lot, washed in running water and hygienized with sodium hypochlorite $(0.005 \%)$. After the removal of excess water, the leaves were submitted to dehydration at different drying conditions, in an air circulation oven (Quimis Model Q-314M292). The dried leaves were ground in a knife mill, stored in aluminum foil-lined plastic bags in nitrogen atmosphere at $-18{ }^{\circ} \mathrm{C}$ for later chemical analysis.

\section{Chemical analysis}

Dried leaf moisture content was determined as described by $\mathrm{AOAC}^{11}$ and the total lipids were determined by the method of Bligh and Dyer. ${ }^{12}$ The fatty acid methyl esters (FAME) were prepared by the method of Joseph and Ackman. ${ }^{13}$ The FAME were analyzed in a Shimadzu 14-A (Kyoto, Japan) gas chromatography equipped with a flame ionization detector (FID) and a fused silica capillary column CP-Select CB-FAME (100 m x $0.25 \mathrm{~mm}$ id., $0.25 \mu \mathrm{m}$ film thickness, Varian, EUA). The operation parameters were as follows: detector temperature, $230^{\circ} \mathrm{C}$; injection temperature, $220^{\circ} \mathrm{C}$; column temperature, from 150 to $185^{\circ} \mathrm{C}$ at $2{ }^{\circ} \mathrm{C} / \mathrm{min}$ and to $225^{\circ} \mathrm{C}$ at $10^{\circ} \mathrm{C} / \mathrm{min}$, final holding time of $20 \mathrm{~min}$; carrier gas, hydrogen at $1.2 \mathrm{~mL} / \mathrm{min}$; make-up, nitrogen gas at $30 \mathrm{~mL} / \mathrm{min}$; split injection at 1:100 ratio. An amount of $2.0 \mu \mathrm{L}$ of each sample was injected into the gas chromatograph nine times. Peak areas were determined in CG-300 Computing integrator (CG Instruments, Brazil) and FAME were identified by comparison with known retention times of standards from Sigma (USA). Fatty acid identification was based on authentic reference standards (Sigma, USA) and equivalent chain-length values (ECL). ${ }^{14,15}$ LNA and other fatty acids were quantified against $\mathrm{C}_{21: 0}$ internal standard from Sigma (USA), as described by Joseph and Ackman. ${ }^{13}$ 
Table 1. Alpha-linolenic acid (LNA) content and moisture (\%) in air circulation oven-dehydrated carrot leaves in preliminary assays carried out with varying time and temperature

\begin{tabular}{|c|c|c|c|c|c|}
\hline \multirow[t]{2}{*}{ Run } & \multirow[t]{2}{*}{$\left(x_{1}, x_{2}\right)$} & \multicolumn{2}{|c|}{ Independent Variables } & \multirow{2}{*}{$\begin{array}{c}{\text { [LNA }]^{\mathrm{a}}}^{(\mathrm{mg} / 100 \mathrm{~g})}\end{array}$} & \multirow{2}{*}{$\begin{array}{c}\text { Moisture }^{\mathrm{b}} \\
(\%)\end{array}$} \\
\hline & & Time (h) & Temperature $\left({ }^{\circ} \mathrm{C}\right)$ & & \\
\hline 1 & $(-1,-1)$ & 41 & 40 & $571^{\mathrm{A}} \pm 60.1$ & $10.15^{\mathrm{A}} \pm 0.03$ \\
\hline 2 & $(+1,-1)$ & 65 & 40 & $653^{\mathrm{AC}} \pm 37.9$ & $7.72^{\mathrm{B}} \pm 0.13$ \\
\hline 3 & $(-1,+1)$ & 41 & 60 & $724^{\mathrm{B}} \pm 51.2$ & $7.65^{\mathrm{B}} \pm 0.17$ \\
\hline 4 & $(+1,+1)$ & 65 & 60 & $669^{\mathrm{BC}} \pm 65.9$ & $7.70^{\mathrm{B}} \pm 0.06$ \\
\hline
\end{tabular}

${ }^{\mathrm{a}}$ Mean values \pm standard deviation $(n=9)$. ${ }^{\mathrm{b}}$ Mean values \pm standard deviation $(n=3) .{ }^{\mathrm{a} \& \mathrm{~b}}$ Means in the same column followed by different letters are significantly different $(p<0.05)$ by Tukey's test.

Table 2. Alpha-linolenic (LNA) content in dehydrated leaves submitted to drying under different time and temperature conditions

\begin{tabular}{|c|c|c|c|c|}
\hline \multirow[t]{2}{*}{ Run } & \multirow{2}{*}{$\left(x_{1}, x_{2}\right)$} & \multicolumn{2}{|c|}{ Independent Variables } & \multirow{2}{*}{$\begin{array}{c}{\left[_{\mathrm{LNA}}\right]^{\mathrm{a}}} \\
(\mathrm{mg} / 100 \mathrm{~g})\end{array}$} \\
\hline & & Time (h) & Temperature $\left({ }^{\circ} \mathrm{C}\right)$ & \\
\hline 1 & $(-1,-1)$ & 29 & 50 & $479^{\mathrm{A}} \pm 18.0$ \\
\hline 2 & $(+1,-1)$ & 53 & 50 & $641^{\mathrm{B}} \pm 28.1$ \\
\hline 3 & $(-1,+1)$ & 29 & 70 & $645^{\mathrm{B}} \pm 24.4$ \\
\hline 4 & $(+1,+1)$ & 53 & 70 & $730^{\mathrm{C}} \pm 31.3$ \\
\hline 5 & $(0,0)$ & 41 & 60 & $714^{\mathrm{C}} \pm 35.7$ \\
\hline 6 & $(0,0)$ & 41 & 60 & $748^{C} \pm 29.6$ \\
\hline $7^{\mathrm{b}}$ & $(0,0)$ & 41 & 60 & $724^{\mathrm{C}} \pm 51.2$ \\
\hline
\end{tabular}

${ }^{a}$ Mean values \pm standard deviation $(n=9)$. Means in the same column followed by different letters are significantly different $(p<0.05)$ by Tukey's test. 'Assay assuming center-point.

\section{Experimental design}

A $2^{2}$ center-pointed factorial design was employed to study response " $y$ " (the LNA content/100 g of dried carrot leaves). ${ }^{16}$ The time $\left(x_{1}\right)$ and temperature $\left(x_{2}\right)$ were used in the dehydration process were the independent inputs studied to optimize " $y$ ". The values for the two inputs used in the center-pointed $2^{2}$ factorial design were chosen from the four preliminary runs shown in Table 1 . The assay for which the conditions gave the best " $y$ " response in preliminary runs (Table 1 ) was taken as the center-pointed $2^{2}$ factorial (Table 2 ). The quadratic polynomial regression model

$y=\beta_{0}+\beta_{I} x_{1}+\beta_{2} x_{2}+\beta_{11} x_{1}^{2}+\beta_{22} x_{2}^{2}+\beta_{12} x_{1} x_{2}$

was assumed to be suitable for predicting the response $(y)$, where $x_{1}$ and $x_{2}$ are coded independent inputs; $\beta_{0}, \beta_{1}, \beta_{2}, \beta_{11}, \beta_{22}, \beta_{12}$, are the parameters to be estimated. The whole design analysis (regression analysis, response surface, and contour plots) were developed using the Design-Expert Software. ${ }^{17}$

\section{Statistical analysis}

The statistical analyses were done as follow: using Statistica Software ${ }^{18}$ to obtain the Tukey's test at $5 \%$ given one-way ANOVA; using Design-Expert Software ${ }^{17}$ for obtaining the ANOVA of factorial analysis.

\section{RESULTS AND DISCUSSION}

Table 1 gives the values of inputs (time and temperature) used in the four runs and the obtained results as well, for the preliminary drying process. No significant difference in carrot leaf moisture was observed (Table 1) in the three samples submitted to the different drying conditions (runs 2-4). The largest moisture content, $10.15 \%$, was observed for leaves dehydrated in run 1 , at mild time and temperature conditions.

The interaction of the times 41 and $65 \mathrm{~h}$ with the temperatures 40 and $60{ }^{\circ} \mathrm{C}$, Table 1 , did not reveal significant differences between run 3 and run 4 (best results). On the other hand, the dehydration at $60^{\circ} \mathrm{C}$ for $41 \mathrm{~h}$ (run 3) was taken as the center-pointed factorial design further developed in this work, because run 3 conditions employed smaller time than run 4 ones. The best results concerning the higher amount of LNA, lower level of moisture and lower time employed indicated the run 3 (Table 1) as good experimental condition for the center-point $2^{2}$ factorial design, further developed in this work for obtaining the quadratic polynomial regression model. The $2^{2}$ factorial was carried out using $12 \mathrm{~h}$ below and above the center-point of $41 \mathrm{~h}$ in association with $10{ }^{\circ} \mathrm{C}$ below and above the center-point temperature of $60{ }^{\circ} \mathrm{C}$. The runs from the combinations used can be seen in Table 2.

\section{Response surface}

The response surface methodology (RSM) is based on the construction of empiric mathematical models. Polynomial functions to describe the studied system are generally employed that allow exploring the system for optimization. ${ }^{16,19}$ This method was used to determine the values for time and temperature inputs that resulted in the best response, that is, the lowest carrot leaf LNA loss as a result of the dehydration during leaf drying.

Variance analysis at $5 \%$ significance level $(\mathrm{p}<0.05)$ showed that the quadratic model proposed was predictive of the LNA concentration in carrot leaves and the $\mathrm{R}^{2}$ value $(0.9884)$ was satisfactory. The model determination coefficient, $\mathrm{R}^{2}$, demon- 
Table 3. ANOVA for factorial analysis

\begin{tabular}{lccccc}
\hline Source & Sum of Squares & DF & Mean Square & F Value & Prob $>$ F \\
\hline Model & 51860.76 & 4 & 12965.19 & 42.46 & 0.0231 \\
Time & 15252.25 & 1 & 15252.25 & 49.95 & 0.0194 \\
Temperature & 16256.25 & 1 & 16256.25 & 53.24 & 0.0183 \\
Time $^{2}$ & 18870.01 & 1 & 18870.01 & 61.80 & 0.0158 \\
Temperature $^{2}$ & 0.00 & 0 & & & 0.1584 \\
Time $x$ Tempera- & 1482.25 & 1 & 1482.25 & 4.85 & \\
ture & 610.67 & 2 & 305.33 & & \\
Pure Error & 52471.43 & 6 & & & \\
Cor Total & & & & & \\
\hline
\end{tabular}

strated that the responses observed fitted the quadratic model. There was no evidence of lack of fitting and the pure error was not significant. The ANOVA concerning the factorial analysis is presented in Table 3.

Both linear and the quadratic terms for the dehydration time were significant. For the temperature of dehydration, only the linear term was significant. The time and temperature interaction parameter was not significant at $95 \%$ confidence.

The largest LNA concentration response in the time and temperature intervals studied was considered for choosing the optimal drying time. The response factor studied presented a linear behavior as a function of the temperature. The response tended to increase linearly with the increase in temperature during drying. Of course, this trend will not be achieved at higher temperatures because the degradation will prevail.

However, in relation to the time variation, the response presented a quadratic behavior. Time affected the LNA content inducing an increase in its response until it reached a maximum and decreased gradually afterwards.

Equation 2 resulted from the estimation of the parameters of Equation 1. It represents the quadratic model

$y=728.67+61.75 x_{1}+63.75 x_{2}-104.92 x_{1}^{2}-19.25 x_{I} x_{2}$

where $x_{1}$ and $x_{2}$ are the codified drying time and temperature and $y$ is the response variable (LNA concentration). Thus, the mathematical model proposes the best experimental conditions, time and temperature, for minimizing the LNA degradation in carrot leaves as being approximately $43 \mathrm{~h}\left(x_{1}=0.167\right)$ and $70{ }^{\circ} \mathrm{C}\left(x_{2}=1.0\right)$.

\section{Total lipids and fatty acid composition in carrot leaves} dehydrated in optimized conditions

Ground dehydrated carrot leaves presented $33.6 \mathrm{mg} / \mathrm{g}$ total lipids on average. LNA predominated in carrot leaves. Research reports that green vegetables contain a relatively high proportion of omega-3, polyunsaturated fatty acids (PUFA), primarily in the form of LNA. ${ }^{20-}$ ${ }^{23}$ The mass percentage of LNA in relation to the other fatty acids quantified was higher than $40 \%$ (Table 4) in carrot leaves dehydrated at $70{ }^{\circ} \mathrm{C}$ for $43 \mathrm{~h}$ (optimized conditions).

Saturated fatty acids (SFA), monounsaturated fatty acids (MUFA), and polyunsaturated fatty acids (PUFA) were also found. The main fatty acids present in carrot leaves were LNA, linoleic acid (LA, 18:2n-6), palmitic acid (16:0), and hexadecatrienoic acid (16:3n-3). Similar results were reported..$^{21-23}$

The main SFA found was palmitic acid, with a concentration of $409 \mathrm{mg} / 100 \mathrm{~g}$ dry matter of dehydrated carrot leaves. Other SFA found were myristic acid (14:0), estearic acid (18:0), behenic acid (22:0) and lignoceric acid (24:0), with concentrations ranging from 9.0 to $45.6 \mathrm{mg} / 100 \mathrm{~g}$ dry matter of dehydrated carrot leaves. Among MUFA, palmitolic acid (16:1n-7) and oleic acid (18:1n-9) were found in concentrations of 46.3 and $69.0 \mathrm{mg} / 100 \mathrm{~g}$ dry matter of dehydrated carrot leaves, respectively.

The LNA concentration of $984 \mathrm{mg} / 100 \mathrm{~g}$ is two-fold that of LA at $467 \mathrm{mg} / 100 \mathrm{~g}$ dry matter of dehydrated carrot leaves. The presence of fatty acid 16:3n-3 in carrot leaves in a significant concentration, $312 \mathrm{mg} / 100 \mathrm{~g}$ dry matter of dehydrated carrot leaves, raised the omega-3 fatty acid sum.

Dry matter LNA was quantified in nine species of vegetables. ${ }^{24}$ The LNA concentration varied from 478 to $1,988 \mathrm{mg} / 100 \mathrm{~g}$ dry matter. The carrot leaves dried in optimized conditions presented a LNA concentration in this range.

The ratio n-6/n-3 fatty acids have an important role in the human diet. According to Simopoulos, ${ }^{25}$ human beings evolved on a diet in which the ratio n-6/n-3 essential fatty acids was about 1-2/1. Today's western cultures have an n-6/n-3 approximately 15 for northern Europe and 16.7 for current US differing from human evolution low ratio. ${ }^{26}$ The optimal balance between dietary LNA and LA has shown to reduce the potential for asthma ${ }^{27}$ and may prevent thrombosis and atherosclerosis. ${ }^{28}$ In contrast, a higher serum n-6/n-3 ratio may increase the risk of coronary heart disease. ${ }^{26}$ The ratio $n-6 / n-3$ fatty acids was 0.36 in the carrot leaves studied.

Table 4. Fatty acid contents in carrot leaves dehydrated in air circulation oven at $70{ }^{\circ} \mathrm{C}$ for $43 \mathrm{~h}$

\begin{tabular}{lc}
\hline Fatty acids & $\mathrm{mg} / 100 \mathrm{~g}$ dry matter \\
\hline $14: 0$ & $16.2 \pm 1.46$ \\
$16: 0$ & $409 \pm 13.5$ \\
$16: 1 \mathrm{n}-7$ & $46.3 \pm 7.01$ \\
$16: 3 \mathrm{n}-3$ & $312 \pm 33.1$ \\
$18: 0$ & $45.6 \pm 3.64$ \\
$18: 1 \mathrm{n}-9$ & $69.0 \pm 1.54$ \\
$18: 2 \mathrm{n}-6$ & $467 \pm 44.6$ \\
$18: 3 \mathrm{n}-3$ & $984 \pm 97.9$ \\
$22: 0$ & $9.0 \pm 1.16$ \\
$24: 0$ & $17.2 \pm 2.14$ \\
\hline
\end{tabular}

Results expressed as means \pm standard deviation $(n=3)$. 
The Institute of Medicine of the United States recommends the daily LNA intake of $1.6 \mathrm{~g} / \mathrm{d}$ for men and $1.1 \mathrm{~g} / \mathrm{d}$ for women aged between 19 and $<70$ years. ${ }^{29}$ As demonstrated in this work, carrot dehydrated at $43 \mathrm{~h}$ and $70^{\circ} \mathrm{C}$ minimize the LNA loss by degradation. So as used as supplementary food, the dehydrated carrot leaves in these optimized conditions may contribute to the recommended daily intake by providing a considerable amount of dietary LNA.

\section{CONCLUSIONS}

In conclusion, the present study showed that carrot leaves may be dehydrated under optimized technological conditions. Air circulation oven dehydration at $70^{\circ} \mathrm{C}$ for $43 \mathrm{~h}$ promotes good protection to the LNA and conserves others fatty acids as well. The average LNA content was determined at $984 \mathrm{mg} / 100 \mathrm{~g}$ of dehydrated carrot leaves. The dehydrated carrot leaves in the optimized conditions $\left[70{ }^{\circ} \mathrm{C}\right.$ for $43 \mathrm{~h}$ ] may provide a considerable amount of dietary LNA as used as supplementary food.

\section{SUPPLEMENTARY MATERIAL}

Available in http://quimicanova.sbq.org.br.

\section{ACKNOWLEDGMENTS}

The authors wish to thank CAPES, CNPQ and Fundação Araucária for financial support.

\section{REFERENCES}

1. Stojceska, V.; Ainsworth, P.; Plunkett, A.; Ibanoglu, E.; Ibanoglu, S.; J. Food Eng. 2008, 87, 554.

2. Stevanato, F. B.; Petenucci, M. E.; Matsushita, M.; Mesomo, M. C.; Souza, N. E.; Visentainer, J. E. L.; Almeida, V. V.; Visentainer, J. V.; Ciênc. Tecnol. Aliment. 2007, 27, 567.

3. Kobori, C. N.; Jorge, N.; Ciênc. Agrotecnol. 2005, 29, 1008.

4. Ferrari, R. A.; Colussi, F.; Ayub, R. A.; Rev. Bras. Frutic. 2004, $26,101$.

5. Oliveira, L. F.; Nascimento, M. R. F.; Borges, S. V.; Ribeiro, P. C. N.; Ruback, V. R.; Ciênc. Tecnol. Aliment. 2002, 22, 259.
6. Pereira, G. I. S.; Pereira, R. G. F. A.; Barcelos, M. F. P.; Morais, A. R.; Rev. Ciênc. Agrotecnol. 2003, 27, 852.

7. Couto, S. R. M.; Derivi, S. C. N.; Mendez, M. H. M.; Higiene Alimentar 2004, 18, 12.

8. Simopoulos, A. P.; Asia Pac. J. Clin. Nutr. 2002, 11, S163.

9. Batista, R. B.; Oliveira, M. G. A.; Pires, C. V.; Lanna, A. C.; Gomes, M. R. A.; José, I. C.; Piovesan, N. D.; Rezende, S. T.; Moreira, R. A.; Quim. Nova 2002, 25, 914.

10. Leonard, A. E.; Pereira, S. L.; Sprecher, H.; Huang, Y.; Prog. Lipid Res. 2004, 43, 36.

11. AOAC - Association of Official Analytical Chemists; Official Methods of Analysi, Washington, DC, 1998, 16 ${ }^{\text {th }}$ ed.

12. Bligh, F. G.; Dyer, W. J.; Can. J. Biochem. Physiol. 1959, 37, 911.

13. Joseph, J. D.; Ackman, R. G.; J. AOAC Int. 1992, 75, 488.

14. Strànsky, K.; Jursík, T.; Vitek, A.; J. High Res. Chromatogr. 1997, $20,143$.

15. Thompson, R. H.; J. Chromatogr. Sci. 1996, 34, 495.

16. Barros Neto, B.; Scarminio, I. S.; Bruns, R. E.; Como fazer experimentos: pesquisa e desenvolvimento na ciência e na indústria, $2^{\mathrm{a}}$ ed., Ed. Unicamp: Campinas, 2002.

17. Stat-Ease; Design-Expert version 6.0.5 Software, Minneapolis, USA, 2001.

18. Statsoft; Statistica 5.0 Software, Tucksa, USA, 1995.

19. Teófilo, R. F.; Ferreira, M. M. C.; Quim. Nova 2006, 29, 338.

20. Vardavas, C. I.; Majchrzak, D.; Wagner, K. H.; Elmadfa, I.; Kafatos, A.; Food Chem. 2006, 99, 822.

21. Pereira, C.; Li, D.; Sinclair, A.; J. Int. J. Vitam. Nutr. Res. 2001, 71, 223.

22. Palaniswamy, U. R.; McAvoy, R. J.; Bible, B. B.; J. Agric. Food Chem. 2001, 49, 3490.

23. Almazan, A. M.; Adeyeye, S. O.; J. Food Comp. Anal. 1998, 11, 375.

24. Liu, L. X.; Howe, P.; Zhou, Y. F.; Hocart, C.; Zhang, R.; J. Food Lipids 2002, 9, 65 .

25. Simopoulos, A. P.; Biomedic. Pharmacot. 2002, 56, 365.

26. Sanders, T.; Oakley, F.; Miller, G.; Mitropoulos, K.; Crook, D.; Oliver, M.; Arterioscler., Thromb., Vasc. Biol. 1997, 17, 3449.

27. Oddy, W. H.; De Klerk, N. H.; Kendall, G. E.; Mihrshahi, S.; Peat, J. K.; J. Asthma 2004, 41, 319.

28. Hu, F.; Manson, J.; Willet, W.; J. Am. Coll. Nutr. 2001, 20, 5.

29. Davis, B. C.; Kris-Etherton, P. M.; Am. J. Clin. Nutr. 2003, 78, 640S. 


\section{OPTIMIZATION OF THE CARROT LEAF DEHYDRATION AIMING AT THE PRESERVATION OF OMEGA-3}

\section{FATTY ACIDS}

Vanessa Vivian de Almeida, Elton Guntendorfer Bonafé, Edvani Curti Muniz, Makoto Matsushita, Nilson Evelázio de Souza e Jesuí Vergílio Visentainer*

Departamento de Química, Universidade Estadual de Maringá, Av. Colombo, 5790, 87020-900 Maringá - PR, Brasil

Table 1S. Original moisture (\%) and LNA content values quantified in mg per $100 \mathrm{~g}$ of dehydrated carrot leaves, submitted to drying under different time and temperature conditions in air-circulation oven (preliminary assays)

\begin{tabular}{|c|c|c|c|c|c|c|c|c|c|c|c|c|c|c|c|c|c|}
\hline \multirow{2}{*}{ Run } & \multirow{2}{*}{$\left(x_{1}, x_{2}\right)$} & \multicolumn{2}{|c|}{ Independent Variables } & \multirow{2}{*}{\multicolumn{9}{|c|}{ LNA (mg/100 g of dehydrated carrot leaves) }} & \multirow{3}{*}{$\begin{array}{c}\text { Mean } \\
\pm \text { S. D. }\end{array}$} & \multirow{2}{*}{\multicolumn{3}{|c|}{ Moisture (\%) }} & \multirow{2}{*}{$\begin{array}{c}\text { Mean } \\
\pm \text { S. D. }\end{array}$} \\
\hline & & Time (h) & Temperature $\left({ }^{\circ} \mathrm{C}\right)$ & & & & & & & & & & & & & & \\
\hline 1 & $(-1,-1)$ & 41 & 40 & 495 & 618 & 615 & 491 & 580 & 623 & 503 & 574 & 643 & & 10.14 & 10.18 & 10.13 & $10.15 \pm 0.03$ \\
\hline 2 & $(+1,-1)$ & 65 & 40 & 667 & 625 & 638 & 674 & 617 & 682 & 613 & 636 & 729 & $653 \pm 37.9$ & 7.57 & 7.76 & 7.82 & $7.72 \pm 0.13$ \\
\hline 3 & $(-1,+1)$ & 41 & 60 & 801 & 743 & 724 & 644 & 652 & 760 & 749 & 700 & 745 & $724 \pm 51.2$ & 7.76 & 7.74 & 7.46 & $7.65 \pm 0.17$ \\
\hline 4 & $(+1,+1)$ & 65 & 60 & 709 & 572 & 595 & 752 & 655 & 694 & 612 & 754 & 678 & $669 \pm 65.9$ & 7.63 & 7.75 & 7.71 & $7.70 \pm 0.06$ \\
\hline
\end{tabular}

Table 2S. Original LNA content values quantified in mg per $100 \mathrm{~g}$ of dehydrated carrot leaves, submitted to drying under different time and temperature conditions

\begin{tabular}{|c|c|c|c|c|c|c|c|c|c|c|c|c|c|}
\hline \multirow{3}{*}{$\begin{array}{c}\text { Run } \\
1\end{array}$} & \multirow{3}{*}{$\frac{\left(x_{1}, x_{2}\right)}{(-1,-1)}$} & \multicolumn{2}{|c|}{ Independent Variables } & \multirow{2}{*}{\multicolumn{9}{|c|}{ LNA (mg/100 g of dehydrated carrot leaves) }} & \multirow{3}{*}{$\begin{array}{r}\text { Mean } \pm \text { S.D } \\
\mathbf{4 7 9} \pm \mathbf{1 8 . 0}\end{array}$} \\
\hline & & \multirow{2}{*}{$\begin{array}{c}\text { Time }(\mathrm{h}) \\
29\end{array}$} & \multirow{2}{*}{$\begin{array}{c}\text { Temperature }\left({ }^{\circ} \mathrm{C}\right) \\
50\end{array}$} & & & & & & & & & & \\
\hline & & & & 497 & 480 & 477 & 486 & 480 & 466 & 511 & 468 & 449 & \\
\hline 2 & $(+1,-1)$ & 53 & 50 & 636 & 628 & 626 & 627 & 687 & 653 & 602 & 683 & 630 & $641 \pm 28.1$ \\
\hline 3 & $(-1,+1)$ & 29 & 70 & 670 & 693 & 622 & 645 & 636 & 641 & 629 & 651 & 615 & $645 \pm 24.4$ \\
\hline 4 & $(+1,+1)$ & 53 & 70 & 751 & 738 & 682 & 741 & 771 & 678 & 725 & 755 & 733 & $730 \pm 31.3$ \\
\hline 5 & $(0,0)$ & 41 & 60 & 759 & 740 & 756 & 710 & 705 & 732 & 688 & 685 & 653 & $714 \pm 35.7$ \\
\hline 6 & $(0,0)$ & 41 & 60 & 727 & 734 & 739 & 720 & 725 & 794 & 728 & 775 & 790 & $748 \pm 29.6$ \\
\hline 7 & $(0,0)$ & 41 & 60 & 801 & 743 & 724 & 644 & 652 & 760 & 749 & 700 & 745 & $724 \pm 51.2$ \\
\hline
\end{tabular}

*e-mail: jvvisentainer@uem.br 